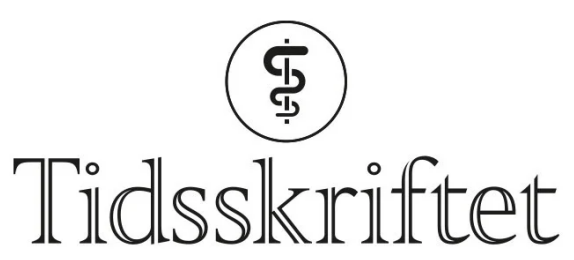

DEN NORSKE LEGEFORENING

\title{
Uklart om viktig emne
}

\author{
ANMELDELSER
}

\section{PÅL GULBRANDSEN}

Helse Øst kompetansesenter for helsetjenesteforskning Akershus universitetssykehus

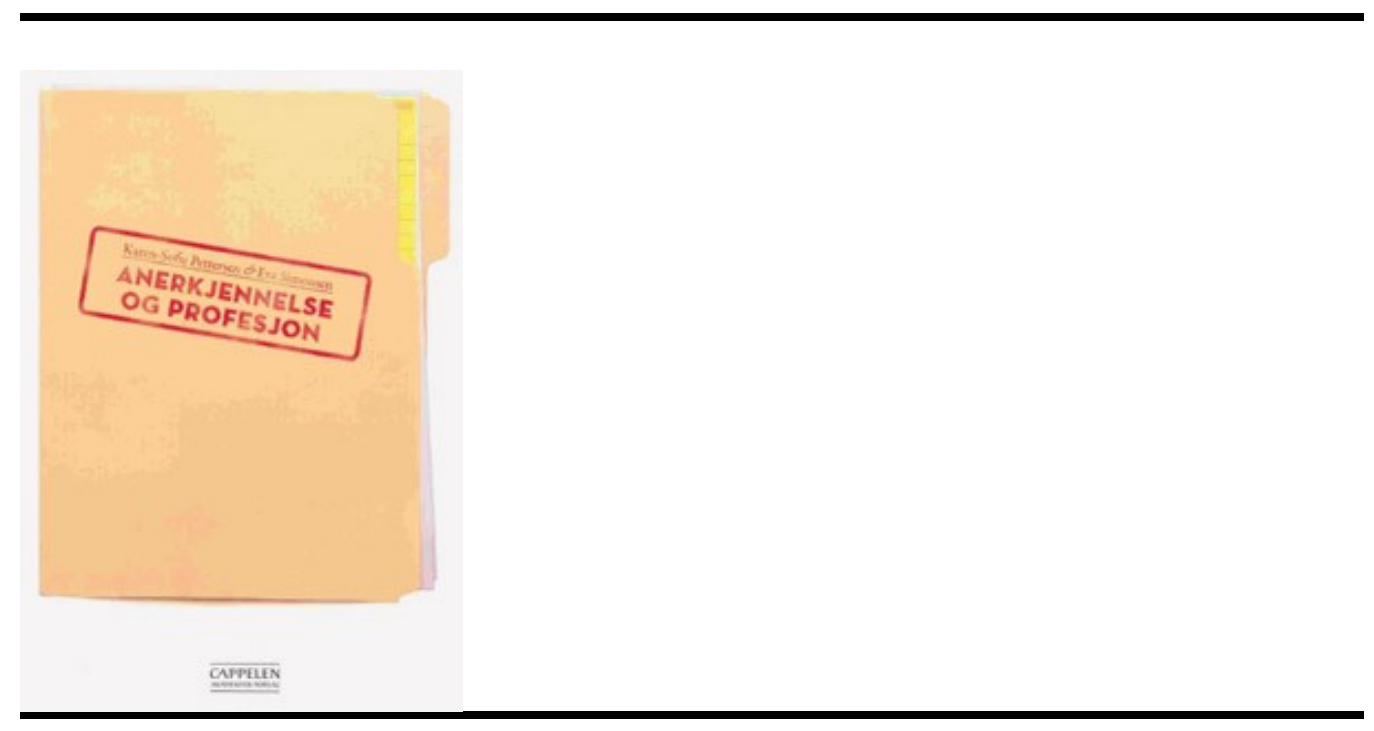

Pettersen, K-S

Simonsen, E.

Anerkjennelse og profesjon

76 s, tab, ill. Oslo: Cappelen Damm, 2010. Pris NOK 248

ISBN 978-82-02-30617-5

Til tross for den noe intetsigende tittelen takket jeg med glede ja til å vurdere denne boken, fordi jeg mener anerkjennelse i for liten grad kommer til uttrykk både i forholdet mellom leger og pasienter, leger og andre helsearbeidere og leger seg imellom. Forfatterne er henholdsvis seniorforsker ved Arbeidsforskningsinstituttet i Oslo og professor ved Institutt for spesialpedagogikk ved Universitetet i Oslo. De burde ha gode forutsetninger etter mange års erfaring fra eget profesjonsutøvende arbeid og undervisning. Forfatterne skriver at formålet er å vise ulike forståelser av hva anerkjennelse innebærer, og hvordan det kan knyttes til velferdsstatens profesjoner og profesjonsutøvelse. 
Boken har fire hovedkapitler foruten innledning og avslutning. I disse knyttes anerkjennelse suksessivt til identitet, omfordeling, profesjonsetikk og frimodighet. Det meste knyttes til en debatt om innholdet i begrepet anerkjennelse, der den tyske sosialfilosofen Axel Honneth (f. 1949) og den amerikanske, politiske filosofen Nancy Fraser (f. 1947) er de sentrale bidragsyterne. Anerkjennelse som fenomen beskrives på individuelt og overordnet politisk nivå, og profesjonsutøvernes vanskelige rolle i midten kommer frem.

I innledningen definerer forfatterne begrepet profesjon over to sider. Som lege finner jeg det underlig at det ikke refereres til Eliot Freidsons sentrale verk fra 1970 (1) om legeprofesjonen, et arbeid som kom til å danne grunnlaget for bøker av samme forfatter om flere profesjoner og mer generelle perspektiver på profesjonenes rolle i samfunnet. Dette viser seg å være den første av flere observasjoner som trekker i retning av at jeg oppfatter boken som et hastverksarbeid. På side 11 legges det opp til en beskrivelse av forhold i Australia, Canada og England. Når utdypningen kommer, er Canada erstattet med Sverige. Filosofen Åge Wifstad omtales minst to ganger som samfunnsmedisiner. Forfatterne argumenterer for større frimodighet, noe jeg ikke er uenig i, og viser det selv i tekst med nokså ureflekterte ytringer: «Å bli miskjent gir en ubalanse i forholdet mellom mennesker, og det innebærer en krenkelse av individets identitet». Denne bruken av begrepet krenkelse representerer etter mitt skjønn en utvidelse og kan lede til inflasjon. Boken er rikt utstyrt med setninger om hva vi skal få høre om senere, og hva vi alt er blitt fortalt. Den korte teksten kunne altså vært betraktelig kortere.

Det får være nok. Heldigvis var det en del å lære hist og her, og det skulle bare mangle fra et akademisk forlag. Litteraturlisten er av verdi. Men kapitlet om formålet var uklart, målgruppen var uklar, argumentasjonen var uklar og konklusjonen uklar. Derfor kan jeg ikke anbefale den, og det er jeg oppriktig lei meg for. En tekst som kunne ha ansporet leger til å ta inn over seg hvor viktig anerkjennelse er, ville vært gull verdt.

\section{LITTERATUR}

1. Freidson E. Profession of Medicine: : A Study of the Sociology of Applied Knowledge. New York, NY: Harper and Row, 1970.

Publisert: 23. september 2010. Tidsskr Nor Legeforen. DOI: 10.4045/tidsskr.10.0699

(C) Tidsskrift for Den norske legeforening 2023. Lastet ned fra tidsskriftet.no 26. april 2023. 